Wahrhafting and H. Eyring, Proc. Natl. Acad. Sci., 38, 667 (1952).

2) W. A. Chupka, J. Chem. Phys., 30, 191 (1959).

3) A. B. King and F. A. Long, 29, 374 (1958).

4) 大村・森戸・中嶋・津山，質量分析，15，51 (1960).
5) 野田・小池, 日立評論, 41, 7 (1959).

6) M. B. Wallenstein, University of Utah (1951).

7) D. P. Stevenson and J. A. Hipple, Jr., T. Am. Chem. Soc., 1588 (1942).

\title{
同位体希釈法によるウラン濃度の測定
}

\section{Determination of Uranium Concentration by Isotope Dilution Method}

小森卓 二**田村修 三*

Takuji Komori and Shuzô Tamura

(1961年 1 月23日受理)

\begin{abstract}
The uranium concentration of the fuel solution in the Water Boiler Type Reactor, which is now in operation at the Japan Atomic Energy Research Institute, was measured by the application of the isotope dilution method usint natural uranium as spike isotopes. After mixing completely, the spike solution with the fuel solution, uranium was separated from fission products by the extraction method using tetrapropylammonium nitrate-methyl, isobutyl ketone system. The is stopic composition of uranium was then measured by means of a surface ionization type mass spectrometer (CEC 21-702B), while the concentration of uranium was calculated from the result of the isotopic assay.

It has been found that this method can be applied with the satisfying reproducibility to the determination of the uranium concentration in the presence of highly radioactive materials.
\end{abstract}

\section{1. 緒言}

原子力研究所に打いて運転されているウォーターボ イラー型原子炬 (JRR-1) の燃料溶液中のウラン濃度 変化の有無を確認するため，天然ウランをスパイクと した同位体希积法によりウラン濃度の測定を行つた。 同位休希釈法をとりあげた理由としては，

i) JRR-1 原子炬燃料六ンの同位体濃度は約 20 $\%{ }^{235} \mathrm{U}$ であるから，スパイクとして天然頻度のウラン が使点ること。

ii）燃料溶液中のウラン湄度が高くても（初めの臨 界特には燃料溶液中のウラン浱度は $183 \mathrm{mg} て ゙$ て た)，スパイクの量を增すことによつて測定が可能とな ること,

iii）はじぬに燃料溶液の試料とスパイクとの混合さ え均一に行なえば，あとの抽汕分離は定量的である必 瑟はないから，この場合のよ5飞高い放射能の溶液の 処理には適していること などであつて，その結果はきわめて良好であつた。

* 日本原子力研究所化学部 (茨城県東海村)

Japan Atonic Energy Research Institute (Tokai-mura, Naka-gun, Ibaraki-ken).

\section{2. 実 験 操 作}

\section{$2 \cdot 1$ 方法の 概 要}

ウラン濃度未知の燃料溶液（約 $20 \%{ }^{235} \mathrm{U}$ ) の一定量 に，渢度既知の天然ウラン溶液（約 $0.7 \%{ }^{235} \mathrm{U}$ ) の一 定显を加兄て均一飞混合し，この混合溶液中のウラン を溶媒抽出法で分離し，その同位体組成を固体想用質 量分析計 (CEC21-702 B M. S.**) で測定し，その結 果から，(1)式を用いて燃料溶液中のウラン薉度を算出 する。

$$
x_{q}=y_{g} \cdot \frac{B_{i k}-C_{i k}}{C_{i k}-A_{i k}} \cdot-b_{k_{-}} \cdot \frac{M_{x}}{a_{k}}
$$

ここに， $x_{g}$ および $y_{g}$ はそれぞれ陚料溶液およびス パイク溶液中のウラン $g$ 数, $A_{i k}, B_{i k}$ および $C_{i k}$ はそ れぞれ試料，スパイク报よび混合溶液中の ${ }^{235} \mathrm{U} /{ }^{238} \mathrm{U}$ $a_{k}$ 捛よび $b_{k}$ はそれぞれ試料拈よびスパイク溶液中の ${ }^{238} \mathrm{U}$ の atom \%，また $M_{x}$ 拈よび $M_{y}$ はそれぞれ試料 拈よびスパイク中のウランの原子量である。

\section{$2 \cdot 2$ 予 備 実 験}

強放射性物質共存下の試料中よりウランを抽出分離 する方法は，2，3 報告12)されているが，ここでは

** CEC21-702 B M. S. については本誌14号, 117 (1960) K 簡単な機器紹介がある。 
tetrapropylammonium nitrate 試衆を用いて, ウラ ンを鍇化合物として, methyl isobutyl ketone 層に抽

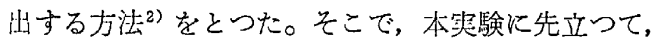
矢際に，核分裂生成物（以下 FP と略す）を含んだ試 料について，この抽出法を用いFP の除去される㓶合 を榆副するとともに, 別にウランの抽出率の確認も行 なつた。

2・2・1 FP 除去の検讨一 $1 \mathrm{ml}$ の FP(約 $0.2 \mu c$ ) をとり，监析剂として硝酸アルミニウムを湑加した $0.1 \%$ tetrapropylammonium nitrate 水溶液 (以下 TPAN 溶液と略す) $8 \mathrm{ml}$ を加え, $4 \mathrm{ml}$ の methyl isobutyl ketone (以下 MIBK と略す) とマグネチッ クスターラーにより 3 分間かきまぜ, 有機層を沪別し た。その約 $2 \mathrm{ml}$ をとり, ポリエチレン管に入れて, シンチレーションカウンターにより主として 数した。この抽出操作を1回の場合と，2回くり返し た堦合について比較した結果，2回の抽出操作でほと んどのFP を除くことができ，括括むねバックグラウ ンドの程度まで放射能を下げられることが判明した。

$2 \cdot 2 ・ 2$ ウラン抽出率の確認——ラン栖準波度
溶液を用いて，その一定最に TPAN 溶液を加光， MIBK とふつて MIBK 層に扠出し，この層から硫酸 アンモニウム水溶液でふたたび水層に逆抽出し，有機 層をのぞく。つぎにこの水首に綏衝溶液を加えて $\mathrm{pH}$ を調節し，30\%の過酸化水䕀を扣充て発色させ， 水で $100 \mathrm{ml}$ にうすめ, スペクトロフォトメーターを 用い, $380 \mathrm{~m} \mu$ の吸光度を测定してウランを定显した。 その結果はウランの抽出率は99\%以上であることが確 認された。

\section{$2 \cdot 3$ 本 実 験}

$2 \cdot 3 ・ 1$ スパイク溶液の調製——スパイク溶液と して天然ウラン (NBS 分析用標準試料) の一定量をと つて, $900^{\circ} \mathrm{C}$ にて 1 㭙間加熱したのち放置して称星, $2 \mathrm{~N}$-硝酸で溶解し，さらに蒸留水で5すめて溶液の全 重最を科量して標集湖度溶液を作つた。

$2 \cdot 3 ・ 2$ スパイクおよび燃料溶液中のウラン同位 体組成の测定—これらの测定は CEC21-702B M. S. を用いて行なつた。このさい，燃料ウランの同位体組 成の測定は，正確には現在（1960年 7 月）に括ける燃 料中のウランについて行らべきであるが，睍在までの

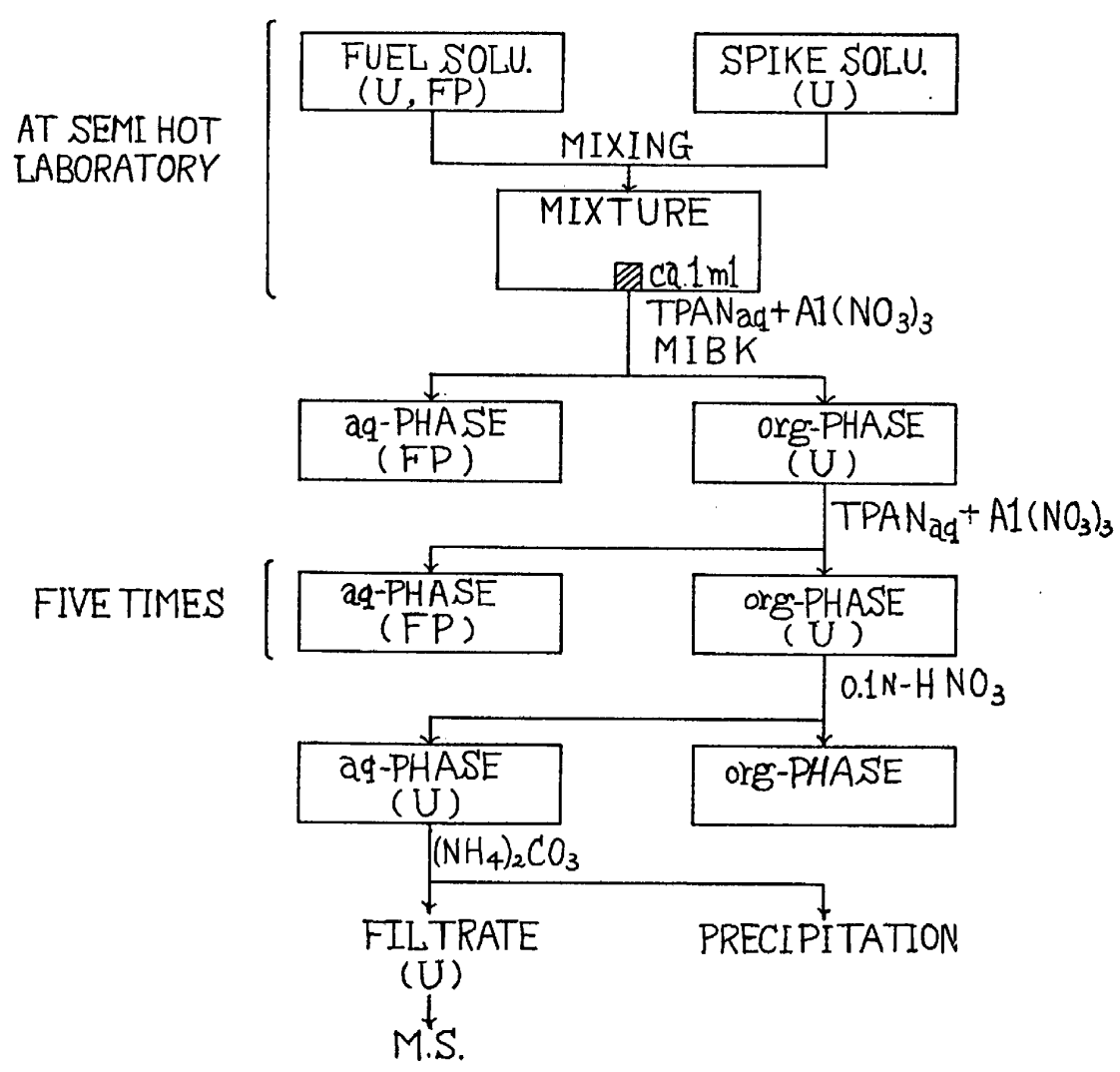

Fig. 1. Schematic diagram of the extraction process. 
燃焼率では，その同位体組成の変化はきわめて小さく， 質量分析計の精度で測定できないから, 初めの臨界時 に使用した燃料の残りすなわち保存燃料について測定 し, 強放射性物質存在下の燃料ウランを抽出分離する 操作を省略した。

2 ・3・3 抽出操作一一掜拌用の回転子を入れた $250 \mathrm{ml}$ の広口ポリエチレン試薬びんにスパイクとし て科量した天然ウラン標準溶液を入れ，あらかじめセ ミホットラボのケーブ内に用意しておく。つぎに，燃 料溶液を風袋の秤量してある $10 \mathrm{ml}$ のポリエチレンび んに入れて化学天科で雬量したのち, ただちにスパイ クを入れた試薬びんに容器もるとる入れる。中でたお して両者を混合し，さらにマグネチックスターラーを 用いて均一に混合した。ここまでの操作はすべて，七 ミホットラボのケーブ内で遠隔操作により行なつた。

このさい, 燃料溶液中のウランは硫酸 ウラニル $\left(\mathrm{UO}_{2} \mathrm{SO}_{4}\right)$ の形であるが，スパイクとして加えた大量 の硝酸ウラニル $\left(\mathrm{UO}_{2}\left(\mathrm{NO}_{3}\right)_{2}\right)$ との間で, ウランの同 位体組成が均一に混合するものと仮定した。

つぎにこれをセミホットラボのケーブょり鉛容器 に入れて取り出し，そのらち約 $1 \mathrm{ml}$ (ウランにして数 $\mathrm{mg}$ 程度）をとつて, TPAN-MIBK 抽出法によつて ウランを FP から抽出分離した。すなわち，TPAN 溶 液 $8 \mathrm{ml}$ を上に述べた混合溶液 $1 \mathrm{ml}$ に加えてよくふ りまぜ, MIBK $4 \mathrm{ml}$ とふつてウランの錯化合物を有 機屈に抽出し，水層と沪別する。この有機層をさらに $8 \mathrm{ml}$ の TPAN 溶液とふつて, FP を, 水層に抽出し てのぞいたのち，有機層について放射能 ( $\gamma$ 線)を測 定したところ，まだバックグラウンド数百倍のカウン 卜数があつたのでささらに TPAN 溶液によるFPの 抽出除去を 4 回繰返した。このようにしてFPをのぞ いた有機層中 (MIBK) のウランを $0.1 \mathrm{~N}$ - 硝酸で水 屬に逆抽出した。このさい，えられたウランの硝酸溶 液にはかなり大量のアルミニウムがらくまれていたの で,この溶液に炭酸アンモンを加えてアルミニウムを 沈澱せしめ,これを沪別したのら沪液は硝酸酸性とな しウオーターバス上で莀縮した。この溶液をミクロピ ペットでフイラメントにつけ，その同位体組成を測定 した。

この場合の抽出操作を Fig. 1 と示す。

\section{3. 実 験 結 果}

Table 1 に実験結果を示す。
Table I. Experimental Results.

\begin{tabular}{|c|c|c|}
\hline Experimental number & 1 & 2 \\
\hline Sample weight $(\mathrm{g})$ & 0.7240 & 0.5227 \\
\hline Spike weight (U) (g) & 0.3207 & 0.1599 \\
\hline${ }^{235} \mathrm{U} /{ }^{238} \mathrm{U}$ in mixture & 0.0658 & 0.0840 \\
\hline $\mathrm{U}$ in sample (g) & 0.1248 & 0.0901 \\
\hline $\begin{array}{l}\mathrm{U} \text { in } 1 \mathrm{~g} \text { sample (g) } \\
\text { (by isotope dilution } \\
\text { method) }\end{array}$ & 0.1715 & 0.1723 \\
\hline $\begin{array}{l}\mathrm{U} \text { in } 1 \mathrm{~g} \text { sample } \\
\text { (by spectrophotometric } \\
\text { method) }\end{array}$ & \multicolumn{2}{|c|}{0.173} \\
\hline \multicolumn{3}{|c|}{$\begin{array}{ll}{ }^{235} \mathrm{U} /{ }^{238} \mathrm{U} \text { in spike }\left(\mathrm{B}_{i k}\right): & 0.00740 \\
{ }^{238} \mathrm{U} \text { atom \% in spike }\left(\mathrm{b}_{k}\right): & 99.26 \\
{ }^{235} \mathrm{U} /{ }^{238} \mathrm{U} \text { in sample }\left(\mathrm{A}_{i k}\right): & 0.2534 \\
{ }^{238} \mathrm{U} \text { atom \% in sample }\left(\mathrm{a}_{k}\right): & 79.50\end{array}$} \\
\hline
\end{tabular}

誤差を扣さえるために，2つのスパイク溶液を用意 乙抢の扮の別々に燃料溶液を加えて実験を行つたが, その結果はきわめてよく一致した。

2 回たけけの実験結果からであるが，この方法の再現 性は非常によく，この誤差は(1)式からもわかるように， 主として質量分析計の誤差によつて支配されるが，分 析対象のウランがかなりひろい濃度範围にわたる場合 でる拈扮むね $1 \%$ 以下（相対誤差）となると思われる。

なお，参考のために試料を約1000倍に希积したのち， オキシン抽出光度法3) でウラン濃度を求めた結果をめ わせ示した。この方法の精度は $5 \%$ 程度であるが, 両 者の一致から考克ても，この方法の测定に信頼がおけ ることは明らかである。 この結諭から, 炉心の燃料溶液に約 $2.5 l$ の水が再結 合器から混入し, ウラン濃度が初めの臨界時に比べて 低下していることが判明した4)。

終りに, この研究を行 $に$ にたつて, 全般的に有益 な助言をいただいた分析化学研究室の本鼠健次室辰に 感謝いたします。

（1960年11月 質量分析研究会年会化て発表）

\section{文献}

1) P. Goris, W. E. Duffy and F. H. Tingey, Anal. Chem., 29, 1590 (1957).

2) W. J. Maeck, G. L. Booman, M. G. Elliott and J. E. Rein, Anal. Chem., 30, 1902 (1958). 3) K. Motojima, H. Yoshida and K. Izawa, Anal. Chem., 32, 1083 (1960).

4) 本島, 他, 日本原子力学会誌 3,55 (1961) 